\title{
KENDALI OPTIMAL MODEL PROGNOSIS SINDROM METABOLIK DENGAN FAKTOR RESIKO OBESITAS DAN DIABETES MELITUS TIPE II MENGGUNAKAN MINIMUM PONTRYAGIN
}

\author{
Nurannisa' ${ }^{1}$ R. Ratianingsih², dan J. W. Puspita ${ }^{3}$ \\ 1,2,3Program Studi Matematika Jurusan Matematika FMIPA Universitas Tadulako \\ Jalan Soekarno-Hatta Km. 09 Tondo, Palu 94118, Indonesia. \\ 1nurannisaahmad36115@gmail.com,2ratianingsih@yahoo.com,3juni.wpuspita@yahoo.com
}

\begin{abstract}
Metabolic syndrome (SM) is a compound of risk factors of cordiovascular disease occurancy. Obesity and type II diabetes mellitus are the main two of the risk factors. The epidemiological data shous that the prevalence of metabolic syndrome in the world is $20-25 \%$. The objective of these research is control to minimize the prognosis of the disease among the SM population that have obesity and type II DM risk factors. The pontryagin minimum principle is used to determine the optimal solution of the prognosis model that the optimal control. The solution is derived from the state and co-state state equations that are evaluated of the drug that give to the sufferer in stationary conditions. The performance Index was designed to minimize the number of SM population that suffer obesity and type II diabetes mellitus and the use of sulfonilurea that given as the normoweighted populations and biguanid for obese populations. The simulation of the optional solution shows that the optimal control was derived to control the number SM that have population of the optional solution obesity and type II DM risk with optimal biguanide $500 \mathrm{mg}$ and sulfonilurea $5 \mathrm{mg}$ as much.
\end{abstract}

Keywords : Metabolic Syndrome, Minimum Pontryagin, Obesity, Stability, Type II Diabetes Mellitus.

\section{ABSTRAK}

Sindrom metabolik (SM) merupakan kumpulan dari faktor-faktor resiko terjadinya penyakit kordiovaskular. Obesitas dan diabetes mellitus tipe II merupakan dua diantara faktor utama tersebut. Data epidemologi menyebutkan prevalensi SM didunia adalah 20-25\%. Penelitian ini bertujuan untuk mendapatkan model pengendalian prognosis SM yang meminimumkan populasi penderita penderita SM dengan faktor resiko obesitas dan DM tipe II. Prinsip minimum Pontryagin digunakan untuk menentukan kendali optimal yang memeberikan solusi optimal kontrol. Solusi tersebut merupakan penyelesaian dari persamaan state dan co-state yang dievaluasi pada kondisi stasioner. Prinsip tersebut juga memberikan Indeks Performance yang dirancang dengan meminimumkan populasi obesitas dan diabetes melitus tipe II, dengan menggunakan terapi obat sulfunilurea untuk populasi berat badan normal dan terapi obat biguanid yang diberiakan kelompok populasi obesitas. Simulasi solusi optimal model pemgendalian prognosis sindrom metabolik memperlihatkan bahwa kendali yang dibangun adalah optimal dalam mengendalikan prognosis penyakit pada kelompok populasi SM dengan pemberian biguanid dan sulfunilurea sebesar $500 \mathrm{mg}$ dan $5 \mathrm{mg}$.

Kata Kunci : Diabetes Mellitus Tipe II , Kestabilan, Minimum Pontryagin, Obesitas, Sindrom Metabolik. 


\section{PENDAHULUAN}

\subsection{Latar Belakang}

Seiring dengan bertambahnya waktu, penderita diabetes melitus (DM) di Indonesia maupun di dunia terus meningkat mengakibatkan bartambahnya penderita Sindrom Metabolik (SM). Sindrom ini merupakan kumpulan dari faktor - faktor resiko terjadinya penyakit kardiovaskular (Rini,2015). Saat ini ada tiga definisi yang biasanya digunakan untuk menjelaskan sindrom metabolik, yaitu definisi WHO, NCEP - ATP III, dan International Diabetes Federation (IDF). Berbagai organisasi telah memberikan definisi yang berbeda, namun seluruh kelompok studi setuju bahwa obesitas, resistensi insulin, dislipidemia, dan hipertensi merupakan komponen utama SM.

Secara global, insiden SM meningkat dengan cepat. Data epidemiologi menyebutkan prevalensi SM dunia adalah 20-25\%. Prevelensi DM tipe II juga meningkat sangat tajam, seiring dengan meningkatnya penderita obesitas. Peningkatan ini diperkirakan akan terus berlanjut. Hal ini dikarenakan penderita obesitas mempunyai resiko tinggi untuk menderita resistensi insulin serta peningkatan kadar gula darah (Purwandari, 2014). Untuk menurunkan kejadian dan keparahan dari DM tipe II maka terdapat pengobatan berupa terapi obat dan non obat. Dua golongan hipoglikemik terapi obat bagi penderita DM tipe II, yaitu golongan sulfoniluera dan biguanid. Golongan sulfoniluera digunakan bagi penderita diabetes dewasa baru dengan berat badan normal dan golongan biguanid digunakan pada penderita diabetes yang obesitas.

Perkembangan ilmu pengetahuan dibidang matematika khususnya pemodelan matematika turut memberi peranan dalam mengatasi fenomena yang ada saat ini, seperti fenomena sindrom metabolik dengan faktor resiko obesitas dan diabetes melitus tipe II. Penelitian terdahulu (Aldila et al., 2014) telah mengkaji model kontrol optimal dari pemberian treatment untuk penderita obesitas di populasi tertutup dengan melibatkan populasi penduduk sehat, overweight dan obesitas yang menggunakan interaksi sosial sebagai penyebab transisi antar kelompok populasi. Model tersebut menjadi dasar pada penelitian ini dalam mengkontruksi model pengendalian prognosis sindrom metabolik dengan faktor resiko obesitas dan diabetes melitus tipe II. Adapun dalam penelitian Lestari (2017) model prognosis diabetes melitus tipe 2 dengan faktor pencetus obesitas dan faktor resiko sindrom metabolik dikontruksi menggunaknan lima subpopulasi yaitu subpopulasi rentan, overweight, obesitas, diabetes melitus tipe 2 , serta sindrom metabolik. Namun, model tersebut belum melibatkan pemberian terapi obat untuk mengendalikan prognosisi diabetes melitus tipe II menuju fase akhir sindrom metabolik. 
Dalam mengkontruksi model pengendalian prognosis, obesitas dipandang sebagai faktor resiko terjadinya DM. Faktor tersebut diklasifikasikan berdasarkan indek masa tubuh (IMT). Adapun penderita DM tipe II yang tidak berhasil menjaga kadar gula darahnya melampaui ambang normal hingga menahun maka penderita tersebut masuk pada fase kronik yang dapat menuju fase akhir yaitu SM. Model yang dibangun dalam penelitian ini merupakan suatu sistem persamaan diferensial (SPD) tak linier yang menggambarkan dinamika setiap kelompok populasi yang melibatkan dalam model, untuk dianalisa kestabilannnya dengan kriteria Routh - Hurwitz.

Dalam penelitian ini, model matematika juga melibatkan pengendalian SM secara non obat yang diwakili oleh parameter - parameter model yang merepresentasikan transisi perpindahan anggota sub populasi rentan, overweight dan obesitas sebagai akibat interaksi sosial. Sedangkan pengendalian berupa terapi obat pada penderita DM tipe II secara matematika dilakukan dengan menggunakan metode minimum pontryagin. Melalui pengontrolan $u_{1}$ dan $u_{2}$ pada nilai parameter $(\theta)$ dan $(\gamma)$ yang secara berturut - turut merepresntasikan tingkat kelahiran alami dan peluang seseorang menderita DM.

\subsection{Rumusan Masalah}

Berdasarkan latar belakang tersebut, permasalahan yang dikemukakan dalam penelitian ini adalah:

1. Bagaimana model pengendalian prognosis sindrom metabolik dengan faktor resiko obesitas dan diabetes melitus tipe II.

2. Bagaimana analisa kestabilan model pengendalian prognosis sindrom metabolik dengan faktor resiko obesitas dan diabetes melitus tipe II menggunakan kriteria Routh - Hurwitz.

3. Bagaimana kendali optimal model pengendalian prognosis sindrom metabolik dengan faktor resiko obesitas dan diabetes melitus tipe II menggunakan metode minimum pontryagin.

\subsection{Tujuan Penelitian}

Adapun tujuan dari penelitian ini adalah:

1. Mendapatkan model pengendalian prognosis sindrom metabolik dengan faktor resiko obesitas dan diabetes melitus tipe II.

2. Mendapatkan analisa kestabilan model pengendalian prognosis sindrom metabolik dengan faktor resiko obesitas dan diabetes melitus tipe II menggunakan kriteria Routh - Hurwitz.

3. Mendapatkan kendali optimal model pengendalian prognosis sindrom metabolik dengan faktor resiko obesitas dan diabetes melitus tipe II dengan menggunakan metode minimum pontryagin. 


\section{METODE PENELITIAN}

Penelitian dilakukan sesuai prosedur di bawah ini:

1. Studi Literatur.

2. Membangun model prognosis sindrom metabolik dengan faktor resiko obesitas dan diabetes melitus tipe II.

3. Menganalisa kestabilan model prognosis sindrom metabolik dengan faktor resiko obesitas dan diabetes melitus tipe II.

4. Penyelesaian kendali optimal model prognosis sindrom metabolik dengan faktor resiko obesitas dan diabetes melitus tipe II.

\section{HASIL DAN PEMBAHASAN}

\subsection{Model Matematika}

Merujuk penelitian (Aldila et al., 2014), pada penelitian ini obesitas dan diabetes melitus tipe II menjadi tahap awal terjadinya Sindrom Metabolik. Indeks masa tubuh (IMT) dijadikan acuan dalam membagi kelompok populasi ke dalam sub populasi berat badan normal $\left(S_{N}\right)$, Overweight $\left(S_{0}\right)$, dan obesitas $(S)$. Obesitas terjadi karena faktor genetik dan interaksi sosial antar kelompok. Transisi dari berat badan normal, overweight dan obesitas diakibatkan adanya interaksi sosial antar kelompok tersebut. Jika tidak ada penanganan pada kelompok obesitas maka anggota kelompok ini akan berlanjut menjadi anggota kelompok diabetes melitus tipe II $(D)$, dan selanjutnya meningkat ke kondisi dimana terjadi komplikasi beberapa penyakit kronik $(K)$, dan pada akhirnya sampai pada fase akhir yaitu sindrom metabolik $(M)$.

Untuk memperlambat seseorang menuju fase sindrom metabolik dilakukan terapi obat menggunakan jenis obat dan dosis yang tepat pada penderita diabetes melitus tipe II dengan menggunakan motode minimum pontryagin. Adapun terapi non obat yang berkaitan langsung terhadap interaksi sosial dari subpopulasi berat badan normal, overweight, dan obesitas. Terapi obat tersebut dilakukan dengan dua kontrol yaitu $u_{1}$ berupa terapi obat golongan sulfunilurea untuk berat badan normal, dan $u_{2}$ berupa terapi obat golongan biguanid untuk penderita obesitas. Diagram kompartemen yang menggambarkan prognosis dari obesitas dan diabetes melitus tipe II yang menjadi faktor utama terjadinya sindrom metabolik dapat dilihat pada Gambar 1. Variabel dan parameter yang terlibat dalam model, disajikan dalam Tabel 1 dan Tabel 2. 


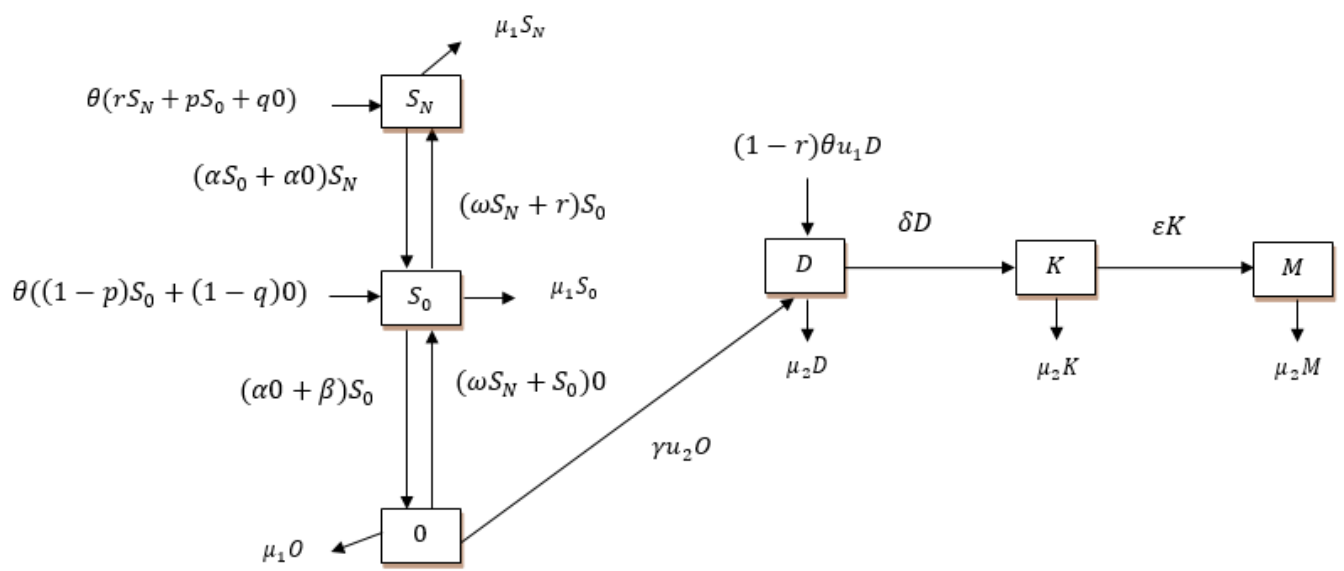

Gambar 1: Komponen Prognosis Obesitas, Diabetes Mellitus Tipe II, Dan Sindrom Metabolik

Berdasarkan diagram kompartemen pada Gambar 1, dibangun model prognosis sindrom metabolik dengan faktor resiko obesitas dan diabetes mellitus tipe II dibangun adalah sebagai berikut:

$$
\begin{aligned}
& \frac{d S_{N}}{d t}=\theta\left(r S_{N}+p S_{o}+q O\right)+\left(\omega S_{N}+\tau\right) S_{o}-\left(\alpha S_{o}+\alpha O\right) S_{N}-\mu_{1} S_{N} \\
& \frac{d S_{o}}{d t}=\left(\alpha S_{o}+\alpha O\right) S_{N}+\theta\left((1-p) S_{o}+(1-q) O\right)+\left(\omega S_{N}+S_{o}\right) O-\mu_{1} S_{o}-(\alpha O+\beta) S_{o} \\
& \frac{d O}{d t}=(\alpha O+\beta) S_{o}-\mu_{1} O-\gamma u_{2} O \\
& \frac{d D}{d t}=\gamma u_{2} O+(1-r) \theta u_{1} D-\mu_{2} D-\delta D \\
& \frac{d K}{d t}=\delta D-\mu_{2} K-\varepsilon K \\
& \frac{d M}{d t}=\varepsilon K-\mu_{2} M
\end{aligned}
$$

Tabel 1: Nilai Awal Variabel

\begin{tabular}{|c|l|c|c|}
\hline variabel & \multicolumn{1}{|c|}{ Keterangan } & Nilai & Sumber (referensi) \\
\hline$S_{N}$ & Populasi dengan berat badan normal & 0.5 & $\frac{\text { jumlah berat badan normal }}{\text { Total populasi }}$ \\
\hline$S_{0}$ & Populasi dengan berat badan berlebih & 0.09 & $\frac{j \text { umlah berat badan berlebih }}{\text { Total populasi }}$ \\
\hline$O$ & Populasi Obesitas & 0.18 & $\frac{\text { jumlah populasi obesitas }}{\text { Total populasi }}$ \\
\hline$D$ & $\begin{array}{l}\text { Populasi penderita diabetes mellitus tipe } \\
\text { II }\end{array}$ & 0.07 & $\frac{\text { jumlah penderita DM tipe II }}{\text { Total populasi }}$ \\
\hline$K$ & $\begin{array}{l}\text { Populasi penderita komplikasi beberapa } \\
\text { penyakit }\end{array}$ & 0.003 & $\frac{\text { jumla penderita kronik }}{\text { Total populasi }}$ \\
\hline$M$ & Populasi penderita sindrom metabolik & 0.001 & $\frac{\text { jumlah penderita SM }}{\text { Total populasi }}$ \\
\hline
\end{tabular}


Tabel 2 : Deskripsi Parameter

\begin{tabular}{|c|c|c|c|c|}
\hline $\begin{array}{l}\text { Parame } \\
\text { ter }\end{array}$ & Deskripsi & Nilai & Dimensi & Sumber \\
\hline$\theta$ & Laju kelahiran Alami & $\frac{1.62}{100}$ & Perhari & $\begin{array}{l}\text { BPS kota } \\
\text { Palu }\end{array}$ \\
\hline$P$ & $\begin{array}{l}\text { Peluang kelahiran dengan berat } \\
\text { badan normal dari kompartemen } \\
\text { overweight }\end{array}$ & 0.01 & Perhari & Asumsi \\
\hline$q$ & $\begin{array}{l}\text { Peluang kelahiran dengan berat } \\
\text { badan normal dari kompartemen } \\
\text { obesitas }\end{array}$ & 0.001 & Perhari & Asumsi \\
\hline$\alpha$ & Laju infeksi karena interaksi & 0.389 & Perhari & $\begin{array}{l}\text { Syarat } \\
\text { stabil }\end{array}$ \\
\hline$\beta$ & $\begin{array}{l}\text { Laju interaksi karena gaya hidup } \\
\text { yang tidak sehat }\end{array}$ & 0.025 & Perhari & $\begin{array}{l}\text { Syarat } \\
\text { stabil }\end{array}$ \\
\hline$r$ & $\begin{array}{l}\text { Peluang kelahiran terjadinya } \\
\text { diabetes mellitus tipe II dari } \\
\text { kompartemen berat badan normal }\end{array}$ & 0.0001 & Perhari & Asumsi \\
\hline$\gamma$ & $\begin{array}{l}\text { Laju transisi sebagai faktor resiko } \\
\text { DM }\end{array}$ & $\frac{1}{4 * 365}$ & Perhari & $\begin{array}{l}\text { Lestari, } \\
2017\end{array}$ \\
\hline$\delta$ & $\begin{array}{l}\text { Laju transisi dari kompartemen DM } \\
\text { ke kompartemen kronik }\end{array}$ & $\frac{1}{5 * 365}$ & Perhari & $\begin{array}{l}\text { Yulian } \\
\mathrm{i}, \\
\text { F.,dkk }\end{array}$ \\
\hline$\varepsilon$ & $\begin{array}{l}\text { Laju transisi dari kompartemen } \\
\text { kronik ke kompartemen kronik ke } \\
\text { kompartemen SM }\end{array}$ & $\frac{1}{15 * 365}$ & Perhari & $\begin{array}{l}\text { Entika, } \\
2017\end{array}$ \\
\hline$\omega$ & Laju kesembuhan karena interaksi & $\frac{53}{200 * 365}$ & Perhari & $\begin{array}{l}\text { Fildes,A., } \\
\text { dkk }\end{array}$ \\
\hline$\tau$ & $\begin{array}{l}\text { Laju kesembuhan karena dorongan } \\
\text { diri sendiri }\end{array}$ & 0.000001 & Perhari & $\begin{array}{l}\text { Syarat } \\
\text { eksis }\end{array}$ \\
\hline$\mu_{1}$ & Laju kematian alami & 0.0000421 & Perhari & $\frac{1}{\text { life time }}$ \\
\hline$\mu_{2}$ & Laju kematian Karen penyakit & $\frac{21}{100000 * 365}$ & Perhari & CDC \\
\hline
\end{tabular}




\subsection{Eksistensi dan Kestabilan Titik Kritis}

Dari model sindrom metabolik dengan faktor resiko obesitas dan diabetes mellitus tipe II diperoleh 2 titik kritis, yaitu titik kritis yang menggambarkan tidak ada populasi yang terinfeksi $\mathrm{T}_{1}=\left(S_{N}, S_{0}, O, D, K, M\right)=(0,0,0,0,0,0)$ dan titik kritis yang menggambarkan endemiknya penyakit diabetes mellitus tipe II $T_{2}$ ditunjukkan secara implisit bergantung pada variabel 0 sebagai berikut :

$$
\begin{aligned}
& D^{*}(O)=\frac{\gamma u_{2} O}{-\theta u_{1}+\theta u_{1} r+\mu_{2}+\delta} \\
& K^{*}(O)=\frac{\gamma u_{2} O \delta}{-\theta u_{1} \mu_{2}-\theta u_{1} \varepsilon+\theta u_{1} r \mu_{2}+\theta u_{1} r \varepsilon+\mu_{2}^{2}+\mu_{2} \varepsilon+\delta \mu_{2}+\delta \varepsilon} \\
& M^{*}(O)=\frac{\gamma u_{2} O \delta \varepsilon}{\mu_{1}\left(-\theta u_{1} \mu_{2}-\theta u_{1} \varepsilon+\theta u_{1} r \mu_{2}+\theta u_{1} r \varepsilon+\mu_{2}^{2}+\mu_{2} \varepsilon+\delta \mu_{2}+\delta \varepsilon\right)} \\
& S_{N}^{*}(O)=\frac{\left(-\theta \mu_{1}-\theta \gamma u_{2}+\theta p \gamma u_{2}-\theta \alpha O-\theta \beta+\theta q \alpha O+\theta q \beta-\mu_{1} O-\gamma u_{2} O+\mu_{1}^{2}+\right.}{\left(\alpha \mu_{1}+\alpha \gamma u_{2}+\alpha^{2} O\right.} \\
& \frac{\left.\mu_{1} \gamma u_{2}+\alpha O \mu_{1}+\alpha O \gamma u_{2}+\mu_{1} \beta+\beta \gamma u_{2}\right)}{+\alpha \beta+\omega \alpha O+\omega \beta)} \\
& S_{0}{ }^{*}(O)=\frac{O\left(\mu_{1}+\gamma u_{2}\right)}{\alpha O+\beta}
\end{aligned}
$$

dengan $O$ adalah akar - akar polinomial berikut ini:

$P(O)=a_{0} O^{3}+a_{1} O^{2}+a_{2} O+a_{3}$

dimana:

$$
\begin{aligned}
a_{0}= & \left((1-\alpha)\left(\gamma u_{2}+\mu_{1}\right)+\theta \alpha+\theta q \omega\right) \alpha^{2} \\
a_{1}= & -\theta^{2} r \alpha^{2}+\omega \mu_{1}^{2} \alpha-2 \alpha^{2} \mu_{1} \beta+\alpha \beta \mu_{1}+\tau \mu_{1} \alpha^{2}+3 \alpha^{2} \mu_{1} \theta+2 \alpha^{2} \theta \beta+\alpha \gamma^{2} u_{2}^{2}-\omega \gamma^{2} u_{2}^{2}- \\
& \alpha^{2} \gamma^{2} u_{2}^{2}+\theta p \gamma u_{2} \omega \alpha+\omega \gamma u_{2} \theta q \alpha-\omega \mu_{1}^{2}-3 \alpha^{2} \mu_{1}^{2}+2 \alpha \mu_{1}^{2}+\theta p \mu_{1} \omega \alpha+2 \theta q \alpha \omega \beta+ \\
& \omega \mu_{1} \theta q \alpha+\theta r \alpha^{2} \gamma u_{2}+\tau \gamma u_{2} \omega \alpha-\theta r \alpha \gamma u_{2}+2 \omega \mu_{1} \alpha \gamma u_{2}-\omega \gamma u_{2} \theta \alpha-\theta r \alpha \mu_{1}+\theta^{2} r \alpha^{2} q+ \\
& \theta r \alpha^{2} \mu_{1}-\theta q \alpha^{2} \mu_{1}-\omega \mu_{1} \theta \alpha+\tau \mu_{1} \omega \alpha+\omega \gamma^{2} u_{2}^{2} \alpha+\tau \gamma u_{2} \alpha^{2}+\alpha \beta \gamma u_{2}-2 \omega \mu_{1} \gamma u_{2}+ \\
& 3 \alpha \mu_{1} \gamma u_{2}-4 \alpha^{2} \mu_{1} \gamma u_{2}+2 \alpha^{2} \gamma u_{2} \theta-2 \alpha^{2} \beta \gamma u_{2} . \\
a_{2}= & \mu_{1} \beta \gamma u_{2}+\mu_{1}^{2} \beta-\theta r \beta \gamma u_{2}-\alpha \beta^{2} \mu_{1}-4 \alpha \mu_{1}^{2} \beta+\tau \mu_{1}^{2} \alpha-\omega \mu_{1}^{2} \theta+\alpha \beta^{2} \theta+\omega \\
& \mu_{1}^{2} \beta+2 \alpha \mu_{1}^{2} \theta+\theta^{2} r \alpha p \gamma u_{2}+\theta r \alpha \mu_{1} \gamma u_{2}+\theta p \gamma u_{2} \omega \beta+\omega \gamma u_{2} \theta q \beta+2 \theta r \\
& \alpha \beta \gamma u_{2}-\theta p \mu_{1} \alpha \gamma u_{2}+2 \theta p \mu_{1} \omega \gamma u_{2}+\omega \mu_{1}^{3}-2 \alpha \mu_{1}^{3}+\theta^{2} r \alpha q \beta++2 \theta^{2} r \alpha \beta \\
& +2 \theta r \alpha \mu_{1} \beta+\theta p \mu_{1} \omega \beta-2 \theta q \beta \alpha \mu_{1}+\omega \mu_{1} \theta q \beta+\omega \gamma^{2} u_{2}^{2} \theta p+\tau \gamma u_{2} \alpha \beta \\
& +\tau \gamma u_{2} \omega \beta-\theta^{2} r \alpha \gamma u_{2}-2 \omega \mu_{1} \theta u_{2}+2 \omega \mu_{1} \beta \gamma u_{2}-\omega \gamma u_{2} \theta \beta+2 \tau \mu_{1} \alpha \gamma u_{2}+ \\
& 3 \alpha \mu_{1} \theta \gamma u_{2}-5 \alpha \beta \mu_{1} \gamma u_{2}+2 \alpha \gamma u_{2} \theta \beta-\theta^{2} r \alpha \mu_{1}-2 \theta^{2} r \alpha \beta+\theta r \alpha \mu_{1}^{2}-\theta p \mu_{1}^{2} \alpha \\
& +\theta q \beta^{2} \omega+\omega \mu_{1}^{2} \theta p-\omega \mu_{1} \theta \beta+\tau \mu_{1} \alpha \beta+\tau \mu_{1} \omega \beta+4 \alpha \mu_{1} \theta \beta-\omega \gamma^{2} u_{2}^{2} \theta \\
& +\omega \gamma^{2} u_{2}^{2} \mu_{1}+\omega \gamma^{2} u_{2}^{2} \beta+\tau \gamma^{2} u_{2}^{2} \alpha+\alpha \gamma^{2} u_{2}^{2} \theta+2 \omega \mu_{1}^{2} \gamma u_{2}-3 \alpha \mu_{1}^{2} \gamma u_{2} \\
& -\alpha \gamma^{2} u_{2}^{2} \mu_{1}-\alpha \gamma^{2} u_{2}^{2} \beta-\alpha \beta^{2} \gamma u_{2}-\theta r \beta \mu_{1} \\
a_{3}= & -\mu_{1}^{2} \beta-\mu_{1}^{2} \beta^{2}-\mu_{1} \beta \theta \gamma u_{2}-\theta^{2} r \beta \mu_{1}+\theta^{2} r \beta^{2} q+\theta r \beta \mu_{1}^{2}+\theta r \beta^{2} \mu_{1}-\mu_{1}^{2} \beta \theta p \\
& -\mu_{1} \beta^{2} \theta q-\mu_{1}^{2} \beta \gamma u_{2}-\theta^{2} r \beta \gamma u_{2}+\mu_{1} \beta \theta \gamma u_{2}+\mu_{1} \beta^{2} \theta+\theta r \beta^{2} \gamma u_{2}+\theta r \beta \\
& \mu_{1 \gamma} u_{2}-\mu_{1} \beta^{2} \gamma u_{2}+\theta^{2} r \beta p \mu_{2}+\theta^{2} r \beta p \gamma u_{2}+\mu_{1}^{2} \beta \theta-\theta^{2} r \beta^{2}
\end{aligned}
$$

Untuk menjamin koeksistensi suatu populasi, diperlukan suatu syarat eksistensi agar banyaknya populasi pada setiap kompartemen $S_{N}, S_{O}, O, D, K, M$ tidak bernilai negatif.Persamaa (1) memiliki dua titik kritis dengan parameter $\theta, p, q, \alpha, \beta, r, \gamma, \delta, \varepsilon, \omega, \tau, \mu_{1}, \mu_{2}, u_{1}, u_{2}>0$. Untuk menjamin eksistensi dari titik kritis endemik $\left(\mathrm{T}_{2}\right)$ digunakan kriteria Descrates, dimana polinomial $P(O)=a_{0} O^{3}+a_{1} O^{2}+a_{2} O+a_{3}$ harus memiliki minimal 1 akar positif. Mengingat polinomial $P(O)$ memiliki $a_{0}>0$ dan $a_{1}>0$ untuk 
nilai $\theta, r, \alpha, \omega, \mu_{1}, \beta, \tau, u_{2}, \gamma, p, q$, yang disubstitusi dari nilai-nilai parameter pada Tabel1 Untuk memperoleh paling sedikit 1 akar positif, haruslah terjadi 1 perubahan tanda. Salah satunya adalah $a_{2}<0$. Sehingga diperoleh syarat eksis dapat dilihat pada hal 9.

Kestabilan dari titik kritis dapat ditentukan melalui tanda negatif dari semua nilai eigen $\lambda$ yang diperoleh dari matriks Jacobi. Matriks Jacobi dari sistem persamaan diferensial (1) yang dievaluasi pada $T_{1}$ memberikan persamaan karateristik dalam $\lambda$ sebagai berikut :

$\left(\lambda-\theta r+\mu_{1}\right)\left(f_{0} \lambda^{5}+f_{1} \lambda^{4}+f_{2} \lambda^{3}+f_{3} \lambda^{2}+f_{4} \lambda+f_{5}\right)=0$

Nilai eigen akan benilai negatif jika memenuhi syarat kestabilan dapat dilihat pada Tabel 3 .

Matriks Jacobi dari sistem persamaan diferensial (4) yang dievaluasi pada $T_{2}$ memberikan persamaan karateristik dalam $\lambda$ sebagai berikut:

$\left(\lambda-\theta u_{1}+\theta u_{1} r+\mu_{2}+\delta\right)\left(\lambda+\mu_{2}+\varepsilon\right)\left(\lambda+\mu_{1}\right)\left(g_{0} \lambda^{3}+g_{1} \lambda^{2}+g_{2} \lambda+g_{3}\right)=0$

Nilai eigen akan benilai negatif jika memenuhi syarat dapat dilihat pada Tabel 3 . 
Tabel 3 : Syarat Eksis dan Stabil

\begin{tabular}{|c|c|c|}
\hline Titik Kritis & Syarat Eksis & Syarat Stabil \\
\hline Bebas penyakit & - & 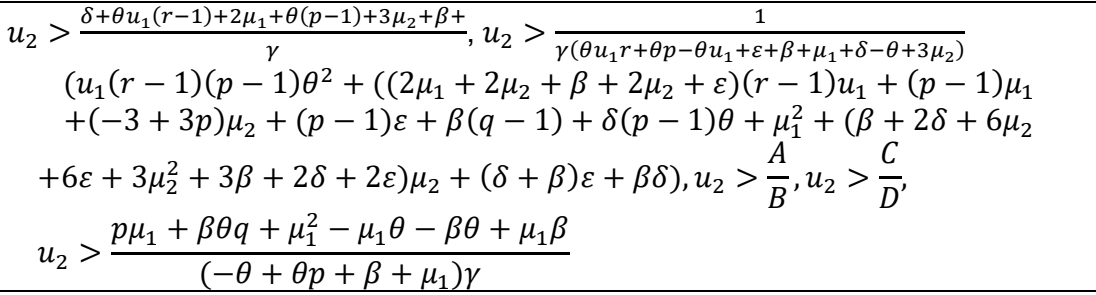 \\
\hline Endemik & $\begin{array}{l}\tau<2 \alpha \mu_{1}^{3}+\left(\left(\theta p+4 \beta+3 \gamma u_{2}\right) \alpha+\omega \theta\right) \mu_{1}^{2}+ \\
\left(\left(\theta^{2} r+\left(2 \beta q+p \gamma u_{2}\right) \theta+\gamma^{2} u_{2}^{2}+\beta^{2}\right.\right. \\
\left.\left.+5 \beta \gamma u_{2}\right) \alpha+\left(2 \omega \gamma u_{2}+\beta(r+\omega)\right) \theta\right) \mu_{1}+ \\
\left(r\left(\gamma u_{2}+2 \beta\right) \theta^{2}+\beta \gamma u_{2}\left(\gamma u_{2}+\beta\right)\right) \alpha \\
\left.\left(\gamma u_{2}+\beta\right)\right) \alpha+\left(\omega \gamma u_{2}+\beta(r+\omega)\right) \theta \gamma u_{2}-r \alpha \\
\left(p u_{1}+2 \beta q+p \gamma u_{2}\right) \theta^{2}+\left(((r+2) \alpha+\omega p) \mu_{1}^{2}\right. \\
+\left(2 \gamma\left(\left(\left(\frac{1}{2} r+\frac{3}{2}\right) \alpha+\omega p\right) u_{2}+\beta+\gamma^{2}+\beta\right.\right. \\
\left.((2 r+2) \alpha+\omega(p+q)) \gamma u_{2}+\beta^{2}(\alpha+\omega q)\right) \\
\theta+\left(\mu_{1}^{3}+\left(\beta+2 \gamma u_{2}\right) \mu_{1}^{2}+\gamma^{2} u_{2}^{2} \mu_{1}+\gamma^{2}\right. \\
\left.+u_{2}^{2} \beta\right) \omega\end{array}$ & $\begin{array}{l}\tau<\frac{N}{Q}, \tau<O\left(O^{4}\left(u_{2} \gamma+\mu_{1}\right) \alpha^{6}+O^{3}\left(u_{2} \gamma+\mu_{1}\right)\left(2 u_{2} \gamma+O \omega+4 \beta+2 \mu_{1}\right) \alpha^{5}\right. \\
+4\left(\left(\frac{3}{2} u_{2} \gamma+\frac{3}{2} \mu_{1} \mu_{1}\right) \beta^{2}+\left(\frac{3}{2} u_{2} \gamma+\frac{7}{4} \mu_{1}+O \omega\right)\left(u_{2} \gamma+\mu_{1}\right) \beta+\frac{1}{4} \mu_{1}^{3}+\left(\frac{1}{4} q \theta+u_{2}\right.\right. \\
\left.\left.+u_{2} \gamma\right) \mu_{2}^{2}+\frac{1}{4} \theta\left(p r q+u_{2} \gamma q\right) \mu_{1}+\frac{1}{4} u_{2} \gamma\left(\gamma^{2} u_{2}^{2}+p q \theta^{2}\right)\right) O^{2} \alpha^{4}+O\left(4 \beta^{3}+\right. \\
\left(6 u_{2} \gamma+8 \mu_{1}+6 O \omega\right) \beta^{2}+\left(\left(\omega \mu_{1}+\theta r\right) O+4 \mu_{1}^{2}+\left(8 u_{2} \gamma+2 q \theta\right) \mu_{1}+2 \gamma^{2} u_{2}^{2}\right. \\
\left.\left.+2 p r \theta^{2}\right) \beta+O \theta\left(((2+r) \omega+r) \mu_{1}+\gamma(r+\omega) u_{2}+p \omega r \theta\right)\right)\left(u_{2} \gamma+\mu_{1}\right) \alpha^{3} \\
+\left(\beta^{4}+\left(2 u_{2} \gamma+4 O \omega+3 \mu_{1}\right) \beta^{3}+\left(\left(2 \omega \mu_{1}+2 \theta r\right) O+3 \mu_{1}^{2}+\left(5 u_{2} \gamma+q \theta\right) \mu_{1}\right.\right. \\
\left.+\gamma^{2} u_{2}^{2}+p r \theta^{2}\right) \beta^{2}+\left(\theta \omega(r+\omega) O^{2}+2 O \theta\left(((2+r) \omega+r) \mu_{1}+\gamma(r+\omega)\right.\right. \\
\left.\left.\left.u_{2}+p \omega r \theta\right)+\mu_{1}\left(u_{2} \gamma+\mu_{1}\right)^{2}\right) \beta+O^{2}\left(u_{2} \gamma+\mu_{1}\right)\left((1+\omega) \mu_{1}+u_{2} \gamma+\omega \theta p\right) \omega\right) \\
\left(u_{2} \gamma+\mu_{1}\right) \alpha^{2}+2 \beta\left(\frac{1}{2} \omega \beta^{3}+\left(\frac{1}{2} \theta r+\frac{1}{2} \omega \mu_{1}\right) \beta^{2}+\left(\omega(r+\omega) O+\left(\left(1+\frac{1}{2} r\right) \omega+\frac{1}{2}\right.\right.\right. \\
\left.r) \mu_{1}+\frac{1}{2} \gamma(r+\omega) u_{2}+\frac{1}{2} p \omega r \theta\right) \theta \beta+\left(\omega O^{2}+\left(u_{2} \gamma+\mu_{1}\right) O+\frac{1}{2}\left(u_{2} \gamma+\mu_{1}\right) \theta\right)\left(u_{2} \gamma\right. \\
\left.+\mu_{1}\right) \\
\\
\quad \\
\text { jika dipilih } \alpha \text { dan } \beta \text { sebagai dalam daerah II dengan memberikan nilai - nilai } \\
\text { yang terdapat pada Tabel } 2 .\end{array}$ \\
\hline
\end{tabular}




\subsection{Penyelesaian Kendali}

Untuk mengendalikan penyebaran penyakit diabetes melitus tipe II maka dilakukan pemberian terapi obat untuk populasi sehat dan populasi obesitas. Secara matematis, masalah pemberian kontrol pada penyebaran penyakit diabetes melitus tipe II direpresentasikan dengan parameter $u_{1}$ sebagai kontrol yang berupa pemberian jenis obat golongan sulfonilurea untuk penderita berat badan normal dan $u_{2}$ sebagai kontrol berupa pemberian jenis obat golongan biguanid untuk penderita obesitas. Pada penyelesaian kendali optimal ini bertujuan untuk meminimalkan populasi yang terinfeksi penyakit diabetes melitus tipe II, sehingga memiliki fungsi tujuan :

$\min J=\int_{t_{0}}^{t_{f}}\left[\frac{1}{2}\left(u_{1}^{2}+u_{2}^{2}\right)+O+D\right] d t$

Dengan kendali tersebut dibentuk fungsi Hamiltonian sebagai berikut:

$H=H\left(x, u_{1}, u_{1}, \lambda, t\right)$

$=V\left(x, u_{1}, u_{1}, t\right)+\lambda f\left(x, u_{1}, u_{1}, t\right)$

$H=\frac{1}{2}\left(u_{1}^{2}+u_{2}^{2}\right)+O+D+\lambda_{1}\left(\theta\left(r S_{N}+p S_{o}+q O\right)+\left(\omega S_{N}+\tau\right) S_{o}-\left(\alpha S_{o}+\alpha O\right) S_{N}-\mu_{1} S_{N}\right)+$ $\lambda_{2}\left(\left(\alpha S_{o}+\alpha O\right) S_{N}+\theta\left((1-p) S_{o}+(1-q) O\right)+\left(\omega S_{N}+S_{o}\right) O-\mu_{1} S_{o}-(\alpha O+\beta) S_{o}+\right.$ $\lambda_{3}\left((\alpha O+\beta) S_{o}-\mu_{1} O-\gamma u_{2} O\right)+\lambda_{4}\left(\gamma u_{2} O+(1-r) \theta u_{1} D-\mu_{2} D-\delta D\right)+\lambda_{5}\left(\delta D-\mu_{2} K-\varepsilon K\right)+$ $\lambda_{6}\left(\varepsilon K-\mu_{2} M\right)$

Dari persamaan (6) diturunkan persamaan state sebagai berikut:

$\dot{S}_{N}=\frac{\partial H}{\partial \lambda_{1}}=\theta\left(r S_{N}+p S_{o}+q O\right)+\left(\omega S_{N}+\tau\right) S_{o}-\left(\alpha S_{o}+\alpha O\right) S_{N}-\mu_{1} S_{N}$

$\dot{S}_{O}=\frac{\partial H}{\partial \lambda_{2}}=\left(\alpha S_{o}+\alpha O\right) S_{N}+\theta\left((1-p) S_{o}+(1-q) O\right)+\left(\omega S_{N}+S_{o}\right) O-\mu_{1} S_{o}-(\alpha O+\beta) S_{o}$

$\dot{O}=\frac{\partial H}{\partial \lambda_{3}}=(\alpha O+\beta) S_{o}-\mu_{1} O-\gamma u_{2} O$

$\dot{D}=\frac{\partial H}{\partial \lambda_{4}}=\gamma u_{2} O+(1-r) \theta u_{1} D-\mu_{2} D-\delta D$

$\dot{K}=\frac{\partial H}{\partial \lambda_{5}}=\delta D-\mu_{2} K-\varepsilon K$

$\dot{M}=\frac{\partial H}{\partial \lambda_{6}}=\varepsilon K-\mu_{2} M$

Dari persamaan (6) diturunkan persamaan co-state sebagai berikut:

$\dot{\lambda}_{1}=-\frac{\partial H}{\partial S_{N}}=-\lambda_{1}\left(\theta r+\omega-\left(\alpha S_{o}+\alpha O\right)-\mu_{1}\right)-\lambda_{2}\left(\alpha S_{o}+\alpha O+\omega O\right)$

$\dot{\lambda}_{2}=-\frac{\partial H}{\partial S_{o}}=-\lambda_{1}\left(\theta p+\tau-\alpha S_{N}\right)-\lambda_{2}\left(\alpha S_{N}+\theta(1-p)+O-\mu_{1}-(\alpha O+\beta)\right)-\quad \lambda_{3}(\alpha O+\beta)$

$\dot{\lambda}_{3}=-\frac{\partial H}{\partial O}=-1-\lambda_{1}\left(\theta q-\alpha S_{N}\right)-\lambda_{2}\left(\alpha S_{N}+\theta(1-q)+\left(\omega S_{N}+S_{o}\right)-\lambda_{3}\left(\alpha S_{o}-\mu_{1}-\gamma u_{2}\right)\right.$ $-\lambda_{4} \gamma u_{2}$

$\dot{\lambda}_{4}=-\frac{\partial H}{\partial D}=-1-\lambda_{4}\left((1-r) \theta u_{1}-\mu_{2}-\delta\right)-\lambda_{5} \delta$

$\dot{\lambda}_{5}=-\frac{\partial H}{\partial K}=\lambda_{5}\left(\mu_{2}+\varepsilon\right)-\lambda_{6} \varepsilon$ 
$\dot{\lambda}_{6}=-\frac{\partial H}{\partial M}=\lambda_{6} \mu_{2}$

Dari persamaan (6) diturunkan persamaan kondisi stasioner sebagai berikut:

$u_{1}=-\lambda_{4}(1-r)$

$u_{2}=-\lambda_{4} \gamma O$

\subsection{Simulasi}

Pada bagian ini akan ditampilkan simulasi berdasarkan ilustrasi dari dinamika model Prognosis sindrom metabolik dengan faktor resiko obesitas dan diabetes mellitus tipe II setelah dilakukan pengontrolan. Adapun hasil simulasi dengan menggunakan nilai awal dimensionless dan nilai-nilai parameter yang ditampilkan pada Tabel 1 dan Tabel 2 dapat dilihat pada Gambar $3-6$.

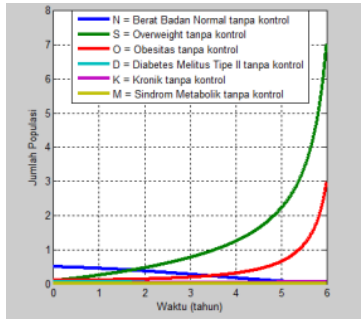

(a)

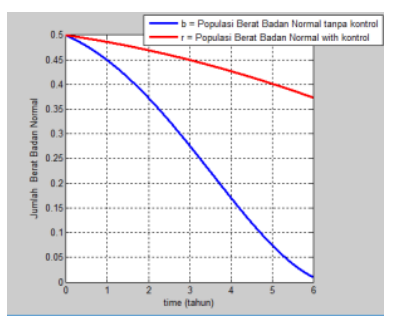

(b)

Gambar 3 : Kurva Simulasi Model Prognosis Sindrom Metabolik Dengan Faktor Resiko

Obesitas Dan Diabetes Mellitus Tipe II (A) Dan Populasi Berat Badan Normal Dengan Kontrol Dan Tanpa Kontrol (B)

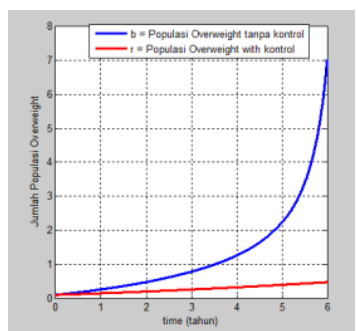

(a)

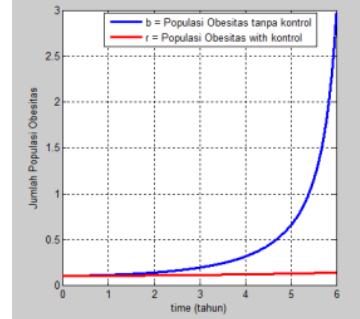

(b)

Gambar 4 : Populasi Overweight Dengan Kontrol Dan Tanpa Kontrol (A) Dan Populasi Obesitas Dengan Kontrol Dan Tanpa Kontrol. 


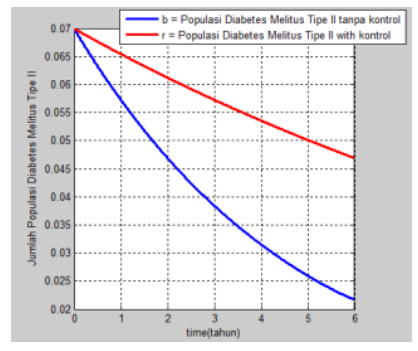

(a)

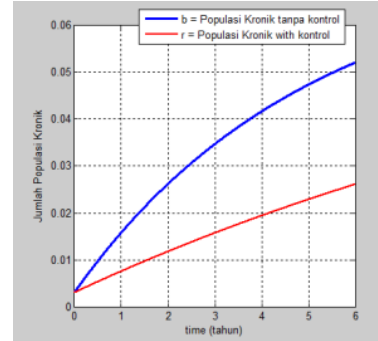

(b)

Gambar 5: Populasi Diabetes Mellitus Tipe II Dengan Kontrol Dan Tanpa Kontrol (A) Dan Populasi Kronik Dengan Kontrol Dan Tanpa Kontrol

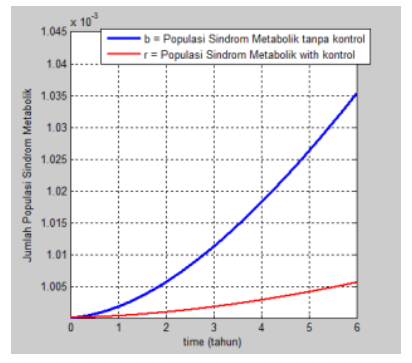

Gambar 6 : Populasi Sindrom Metabolik Dengan Kontroldan Tanpa Kontrol

Gambar 3a memperlihatkan dinamika populasi manusia seiring dengan perubahan waktu dengan nilai awal dan parameter yang dinyatakan pada Tabel 1 dan Tabel 2. Gambar 3a menunjukkan bahwa banyaknya anggota subpopulasi manusia dengan berat badan normal akan menurun seiring dengan bertambahnya populasi manusia dengan berat badan berlebih atau overweight dan anggota populasi manusia yang mengalami obesitas. Dengan peningkatan anggota populasi obesitas maka banyaknya penderita diabetes mellitus tipe II juga akan mengalami peningkatan. Populasi diabetes mellitus tipe II mengalami penurunan karena kematian dan meningkatnya anggota populasi kronik dan sindrom metabolik. Gambar $2 \mathrm{~b}$ memperlihatkan kurva banyaknya populasi berat badan normal yang diberikan nilai awal 0.5 saat $t=0$ yang memberi arti pada mulanya $50 \%$ populasi memiliki berat badan normal. Dari gambar tesebut, pada tahun ke 3 sebelum pemberian kontrol banyaknya anggota subpopulasi berat badan normal yaitu $28 \%$. Namun, setelah diberikan kontrol $u_{1}$ bagi berat badan normal dan $u_{2}$ bagi penderita obesitas, maka banyaknya subpopulasi normal mengalami kenaikan menjadi $45 \%$ meskipun pada akhirnya kedua keadaan tersebut menunjukkan penurunan anggota subpopulasi. Penurunan banyaknya anggota sub populasi berat badan normal yang tidak diberikan kontrol akan mengalami penurunan yang lebih signifikan. Dari hal tersebut dapat diketahui bahwa pemberian kontrol mempengaruhi dinamika populasi, dimana sub populasi berat badan normal lebih banyak dibandingkan 
dengan populasi berat badan normal tanpa kontrol. Hal ini terjadi karena subpopulasi overweight dan obesitas bertransisi kembali ke subpopulasi berat badan normal.

Gambar 4a memperlihatkan kurva subpopulasi overweight yang diberikan nilai awal sebesar 0.09 saat $t=0$ yang berarti bahwa terdapatnya $9 \%$ populasi pada keadaan awal. Pada rentang waktu lebih dari 3 tahun, banyaknya anggota subpopulasi overweight tanpa pemberian kontrol meningkat sangat pesat dibandingkan dengan pemberian kontrol berupa obat. Sebagai contoh, pada tahun ke 3 sebelum pemberian kontrol banyak anggota subpopulasi overweight yaitu $90 \%$. Namun, setelah diberikan kontrol $u_{1}$ bagi berat badan normal dan $u_{2}$ bagi penderita obesitas, maka banyaknya subpopulasi overweight mengalami penurunan menjadi $15 \%$. Gambar $3 \mathrm{~b}$ memperlihatkan kurva sub populasi obesitas yang diberikan nilai awal 0.18 saat $t=0$ yang berarti bahwa terdapat $18 \%$ populasi pada keadaan awal. Pada rentang waktu lebih dari 3 tahun, banyaknya anggota subpopulasi meningkat sangat signifikan. Sebagai contoh, pada tahun ke 5 sebelum pemberian kontrol banyaknya anggota subpopulasi obesitas yaitu $70 \%$. Namun, setelah diberikan kontol $u_{1}$ dan $u_{2}$ subpopulasi tersebut mengalami penurunan yaitu $20 \%$ jika dibandingkan sebelum pemberian kontrol.

Gambar 5a memperlihatkan kurva banyaknya populasi diabetes mellitus tipe II yang diberi nilai awal sebesar 0.07 yang memberi arti pada mulanya 7\% populasi menderita diabetes mellitus tipe II. Dari gambar tersebut, pada tahun ke 3 banyaknya anggota subpopulasi diabetes mellitus tipe II sebelum pemberian kontrol yaitu $3.9 \%$. Namun, setelah pemberian kontrol $u_{1}$ dan $u_{2}$ jumlah populasinya tersebut meningkat menjadi $5.9 \%$ jika bandingkan sebelum pemberian kontol. Hal ini disebabkan karena subpopulasi diabetes mellitus tipe II dengan pemberian kontrol tidak membuat seseorang akan sembuh, namun untuk menjaga gula darahnya tetap terkontrol dan memperlambat masa hidup dari subpopulasi tersebut. Gambar 4b memperlihatkan untuk kurva subpopulasi kronik yang diberikan nilai awal sebesar 0.003 yang berarti bahwa terdapatnya $0.3 \%$ jumlah populasi yang penderita kronik. Pada rentang waktu lebih dari 3 tahun, banyaknya anggota subpopulasi kronik tanpa pemberian kontrol meningkat sangat pesat dibandingkan dengan pemberian kontrol berupa obat. Sebagai contoh, pada tahun ke 3 banyaknya anggota subpopulasi kronik sebelum pemberian control yaitu $3.5 \%$. Namun, setelah diberikan kontrol $u_{1}$ dan $u_{2}$ maka banyaknya subpopulasi kronik menurun menjadi $1.8 \%$.

Gambar 6 memperlihatkan untuk kurva subpopulasi sindrom metabolik yang diberikan nilai awal sebesar 0.001 yang berarti bahwa terdapatnya $0.1 \%$ jumlah populasi yang penderita sindrom metabolik. Pada rentang waktu lebih dari 3 tahun, banyaknya anggota subpopulasi sindrom metabolik tanpa pemberian kontrol meningkat sangat pesat dibandingkan dengan pemberian kontrol berupa obat. Sebagai contoh, pada tahun ke 1 
banyaknya anggota subpopulasi sindrom metabolik sebelum pemberian kontrol yaitu $0.5 \%$. Namun, setelah diberikan kontrol $u_{1}$ dan $u_{2}$ maka banyaknya subpopulasi kronik menurun menjadi $0.25 \%$.

\section{KESIMPULAN}

Dari kendali optimal model prognosis sindrom metabolik denag faktor resiko obesitas dan diabetes mellitus tipe II diperoleh 2 titik kritis, yaitu titik kritis yang menggambarkan kondisi bebas penyakit dan titik kritis yang menggambarkan kondisi endemik penderita diabetes mellitus tipe II. Eksistensi dan kestabilan dari titik kritis $T_{1}$, dan $T_{2}$ dapat dijamin dalam penelitian ini. Menggunakan metoda Minimum Pontryagin yang mempunyai fungsi tujuan meminimalkan populasi yang terinfeksi penyakit diabetes mellitus tipe II dengan Indeks Performance $\min J=\int_{t_{0}}^{t_{f}}\left[\frac{1}{2}\left(u_{1}{ }^{2}+u_{2}{ }^{2}\right)+O+D\right] d t$ dan kondisi satasioner $\mathrm{u}_{1}=-\lambda_{4}(1-r)$, dan $\mathrm{u}_{2}=-\lambda_{4} \gamma O$, berdasarkan hasil simulasi menunjukkan bahwa kendali yang dibangun adalah optimal untuk mengendalikan populasi yang terinfeksi diabetes mellitus tipe II.

\section{DAFTAR PUSTAKA}

[1] Aldila, D., Rarasati, N., and Soewono, E, Optimal Control Problem of Treatment for Obesity in a Closed Population, Institut Teknologi Bandung, 2014, Bandung.

[2] [CDC] Center for Disiase Control and Prevation, 2015, Diperoleh dari website CDC: http://www.cdc.gov/nchs/hus.htm,Diakses pada 25 Mei 2017.

[3] Entika, H. R, Hubungan Status Gizi dan Sindrom Metabolik dengan Kejadian Komplikasi Pasien DM Tipe 2 Rawat Jalan di RSUD DR. Moewardi, Fakultas IImu Kesehatan, Universitas Muhammadiyah Surakarta , 2017, Surakarta.

[4] Lestari, D. A, Analisa Kestabilan Model Prognosis Diabetes Mellitus Tipe 2 dengan Faktor Pencetus Obesitas dan Faktor Resiko Sindrom Metabolik, Fakultas Matematika dan IImu Pengetahuan Alam Universitas Tadulako, 2017, Palu.

[5] Purwandari, H, Hubungan Obesitas dengan Kadar Gula Darah pada Karyawan di RS Tingkat IV Madiun, Efektor,1(25),65-74,2014,http://lp2m.unpkediri.ac.id/jurnal/pages/efektor/, Diakses pada 19 juli 2017.

[6] Rini,S, Sindrom Metabolik, J majority, 4 (4) 88 - 93 , 2015, http://juke.kedokteran.unila .ac.id/index.php/majority/, Diakses pada tanggal 20 Juli 2017

[7] Yuliani, F., Oenzil, F., Iryani.,D, Hubungan Berbagai Faktor Resiko Terhadap Kejadian Penyakit Jantung Coroner Pada Penderita Diabetes Mellitus Tipe 2, Jurnal Kesehatan Andalas, 3(1),39-40, 2014. 